\title{
Two-phase Flow in Fuel Cells in Short-term Microgravity Condition
}

\author{
Hang Guo • Jian Fu Zhao • Fang Ye • Feng Wu • \\ Cui Ping Lv • Chong Fang Ma
}

Received: 12 February 2008 / Accepted: 3 June 2008 / Published online: 25 June 2008

(C) Springer Science + Business Media B.V. 2008

\begin{abstract}
A visual observation of liquid-gas two-phase flow in anode channels of a direct methanol proton exchange membrane fuel cells in microgravity has been carried out in a drop tower. The anode flow bed consisted of 2 manifolds and 11 parallel straight channels. The length, width and depth of single channel with rectangular cross section was $48.0 \mathrm{~mm}, 2.5 \mathrm{~mm}$ and $2.0 \mathrm{~mm}$, respectively. The experimental results indicated that the size of bubbles in microgravity condition is bigger than that in normal gravity. The longer the time, the bigger the bubbles. The velocity of bubbles rising is slower than that in normal gravity because buoyancy lift is very weak in microgravity. The flow pattern in anode channels could change from bubbly flow in normal gravity to slug flow in microgravity. The
\end{abstract}

Paper was submitted on the Third International Topical Team Workshop on Two-phase System for Space and Ground Applications, September 10-12, 2008, Brussels, Belgium

H. Guo $(\varangle) \cdot$ F. Ye · F. Wu · C. P. Lv · C. F. Ma

Key Laboratory of Enhanced Heat Transfer

and Energy Conservation, Ministry of Education,

College of Environmental and Energy Engineering,

Beijing University of Technology,

100 Ping Le Yuan, Chaoyang District,

Beijing 100124, People's Republic of China

e-mail: hangguo@sohu.com

H. Guo $\cdot$ F. Ye $\cdot$ F. Wu $~$ C. P. Lv · C. F. Ma

Key Laboratory of Heat Transfer and Energy Conversion, Beijing Municipality, Beijing University of Technology,

Beijing 100124, People's Republic of China

\section{J. F. Zhao}

Institute of Mechanics, Chinese Academy of Sciences,

Beijing 100080, People's Republic of China gas slugs blocked supply of reactants from channels to anode catalyst layer through gas diffusion layer. When the weakened mass transfer causes concentration polarization, the output performance of fuel cells declines.

Keywords Fuel cells • Two-phase flow • Microgravity

\section{Introduction}

Fuel cells, which can continuously convert the chemical energy of the fuel and the oxidant directly into electrical energy, have drawn increasing attention again in recent years.

The first practical working fuel cells in spaceflight were developed by General Electric Company in the 1960s for NASA's Gemini space missions. At that time, the proton exchange membrane fuel cells (PEMFCs) acted as auxiliary power of the spacecraft. The sulphonated polystyrene ion-exchange membrane was used as electrolyte of fuel cells. In 1960s, Pratt and Whitney Company developed the alkaline fuel cells (AFCs) for Apollo space missions. From that time, AFCs were used in some of subsequent aerospacecrafts including Space Shuttles.

Being different from previous generation of PEMFCs, the electrolyte of proton exchange membrane fuel cells is perfluorosulphonated membrane in the past two decades. Performance, reliability and lifetime of proton exchange membrane fuel cells were significantly improved. The main types of PEMFCs are hydrogen PEMFCs (including fuel reforming fuel cells) and direct methanol fuel cells (DMFCs). PEMFCs are considered as a promising choice for primary or auxiliary power devices in the next generation of 
spacecrafts (Sone et al. 2004, 2006; Barbir et al. 2005). However, the application of the new generation of PEMFCs in aerospace is still in the initial stage.

The performance of PEMFCs is related to not only electrochemical reactions, but also transport phenomena, such as two-phase flow and heat /mass transfer inside fuel cells. For example, liquid fed direct methanol proton exchange membrane fuel cells, which could be considered as the power sources for the small unaided devices such as carried experimental equipments in satellites or spacecrafts, undergo following electrochemical reactions:

$$
\begin{aligned}
& \text { Anode: } \mathrm{CH}_{3} \mathrm{OH}+\mathrm{H}_{2} \mathrm{O} \rightarrow \mathrm{CO}_{2}+6 \mathrm{H}^{+}+6 \mathrm{e}^{-} \\
& \text {Cathode: } \frac{3}{2} \mathrm{O}_{2}+6 \mathrm{H}^{+}+6 \mathrm{e}^{-} \rightarrow 3 \mathrm{H}_{2} \mathrm{O} \\
& \text { Overall: } \mathrm{CH}_{3} \mathrm{OH}+\frac{3}{2} \mathrm{O}_{2} \rightarrow 2 \mathrm{H}_{2} \mathrm{O}+\mathrm{CO}_{2}
\end{aligned}
$$

There are the aqueous methanol solution (reactant) and the carbon dioxide (product of electrochemical reaction) in the anode side of liquid fed direct methanol proton exchange membrane fuel cells. Carbon dioxide dissolvability in liquid water-methanol mixtures is fairly low. The anode side is a liquid-gas two-phase system primarily consisting of methanol solution and $\mathrm{CO}_{2}$ bubbles. Many researchers performed experiments of fluid flow and mass transfer in DMFCs (Scott et al. 1999, 2001; Argyropoulos et al. 1999a, b; Lu and Wang 2004; Nordlund et al. 2004; Yang et al. 2005a, b, 2007; Guo et al. 2003, 2006; Zhang et al. 2007) and hydrogen PEMFCs (Guo et al. 2003; Mench et al. 2003; Tüber et al. 2003; Hakenjos et al. 2004; Yang et al. 2004; Zhang et al. 2006; Liu et al. 2006, 2007) under normal gravity. However, microgravity experiments of two-phase flow in fuel cells, which adopted perfluorosulphonated proton exchange membrane as electrolyte, are still lacking in the open literature.

In this paper, an in situ visual observation of twophase flow inside direct methanol proton exchange membrane fuel cells in microgravity was conducted. The effect of gravity on two-phase flow and mass transfer in fuel cells was analyzed and discussed.

\section{Experimental}

The sketch of the experimental system is shown in Fig. 1. A high speed video camera (VITcam CTC) with a SE2514 lens was employed to record two-phase flow images in the anode flow field. The resistance was adopted as electric load in external circuit of the fuel cell. Experimental data, including microgravity signal,

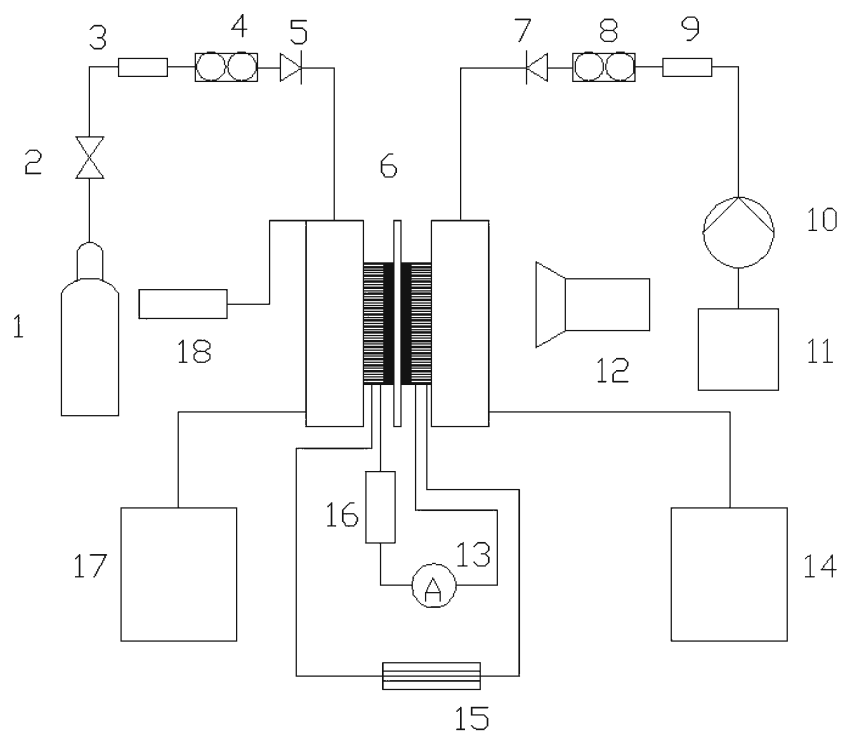

Fig. 1 Experimental set-up. (1) oxygen tank; (2) regulator; (3) filter; (4) flow rate controller; (5) check valve; (6) fuel cell; (7) check valve; (8) flow rate meter; (9) filter; (10) peristaltic pump; (11) liquid storage bag; (12) high speed video camera; (13) current transmitter; (14) liquid collector; (15) data acquisition unit; (16) electric resistors; (17) exhaust collector; (18) temperature control and heating unit

fuel cells temperature, current, voltage, flow rate of methanol solution and oxygen gas, etc., were collected into a data acquisition unit (AQU1216).

In our single fuel cell, a membrane electrode assembly (MEA), which had an active area of $5.0 \times 5.0 \mathrm{~cm}^{2}$, consisted of a Nafion 117 membrane and two carbon cloth gas diffusion layers (GDL). The $4 \mathrm{mg} / \mathrm{cm}^{2} \mathrm{PtRu}$ and $4 \mathrm{mg} / \mathrm{cm}^{2} \mathrm{Pt}$ were adopted as anode and cathode catalysts, respectively. The MEA was sandwiched between two bipolar plates.

In Guo et al. (2008), the authors reported microgravity experiments of fuel cells with gold plated stainless steel bipolar plates. In this paper, however, both anode and cathode bipolar plates were made of graphite. The flow channels were machined on the surface of bipolar plates to form flow bed. The cathode flow bed was a single serpentine channel with rectangular cross section. The anode flow bed, which had 11 parallel straight flow channels with rectangular cross section was fitted in tested single fuel cell. The length of single anode channel is $48.0 \mathrm{~mm}$. On both anode and cathode side, channel depth, channel width and width of ridge between two channels were $2.0 \mathrm{~mm}, 2.5 \mathrm{~mm}$ and $2.0 \mathrm{~mm}$, respectively. A transparent end plate in anode side was made of polycarbonate for visual observation. In all experiments of this paper, all anode channels were vertical, the anode inflow manifold was in the bottom of flow bed, and the outflow manifold was on the top 


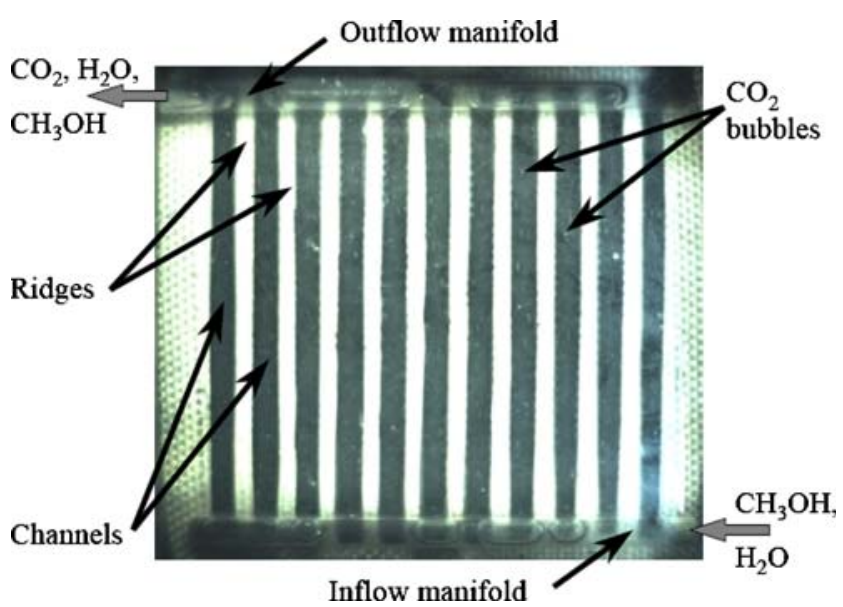

Fig. 2 Two-phase flow in anode flow bed of a DMFC in normal gravity (40 ms before microgravity)

(Fig. 2). This arrangement smoothed the way for $\mathrm{CO}_{2}$ bubbles removal. In the cathode side, the inlet was in the top and the outlet was in the bottom for the discharge of excessive liquid water.

Microgravity experiments were carried out in National Microgravity Laboratory, Chinese Academy of Sciences. A drop tower could provide $3.6 \mathrm{~s}$ effective microgravity environment. The residual acceleration of gravity during free fall of capsule, in which was fixed our fuel cells experimental system, was less than $10^{-2} \mathrm{~g}_{0}$ $\left(\mathrm{g}_{0}=9.81 \mathrm{~m} / \mathrm{s}^{2}\right)$.

\section{Results and Discussion}

In all experiments reported in this paper, the fuel cell was operated at $80^{\circ} \mathrm{C}$. Methanol solution with molarity of $0.5 \mathrm{~mol} / \mathrm{l}$ was supplied to anode flow bed at flow rate of $6 \mathrm{ml} / \mathrm{min}$. The inlet flow rate of pure oxygen was maintained at $400 \mathrm{ml} / \mathrm{min}$.. The pressures in anode and cathode outlet were $0 \mathrm{kPa}$ gauge. To insure steady state operation of the fuel cell before microgravity, the fuel cell had run for $70 \mathrm{~min}$ in above-mentioned operating condition in normal gravity before every microgravity experiment.

An in situ image of two-phase flow in anode flow bed of a liquid fed direct methanol proton exchange membrane fuel cell in normal gravity is shown in Fig. 2. It was taken at $40 \mathrm{~ms}$ before microgravity. The picture showed that carbon dioxide, which was produced in anode catalyst layer and went through carbon cloth porous media, flowed into liquid mainstream in anode channels and formed bubbly flow. The average rise velocity of bubbles, which was calculated based on images taken by high speed video camera, was $148 \mathrm{~mm} / \mathrm{s}$. Considering the mean velocity of liquid at the entry of channel was $1.82 \mathrm{~mm} / \mathrm{s}$, which was calculated from inlet flow rate of methanol solution, the speed of bubbles removal was quite fast because of buoyant lift force. The bubbles in channels were still small and scattered. They moved with mainstream of methanol solution to the outflow manifold. The diameter of most bubbles in channels was not bigger than $1 \mathrm{~mm}$.

Forty milliseconds later, the capsule, which contained our fuel cells experimental system, was released from upper story of drop tower in $83 \mathrm{~m}$ above the ground. If set the moment of releasing capsule as the starting time of microgravity, we could obtain twophase flow in anode channels of the fuel cell at different moments in microgravity condition (Fig. 3). The results of visual observation showed that, in microgravity, the $\mathrm{CO}_{2}$ bubbles could not get away from the surface of GDL in time. At the beginning, the bubbles accreted on the wall of carbon cloth surface. Then, the bubbles grew gradually because of producing carbon dioxide

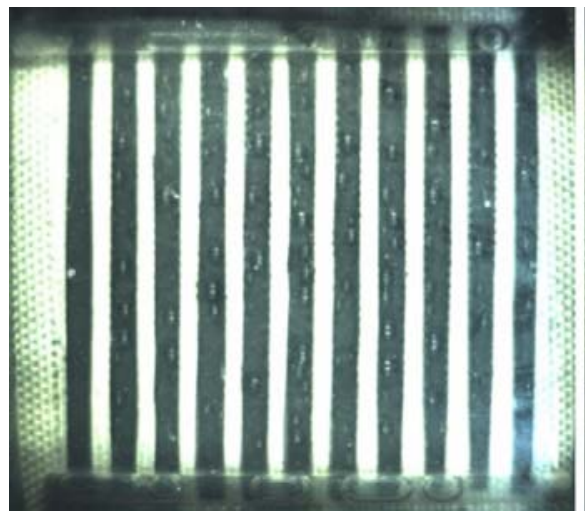

(a)

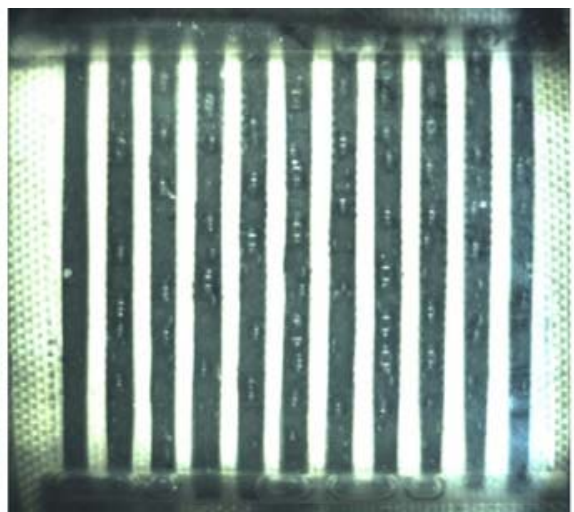

(b)

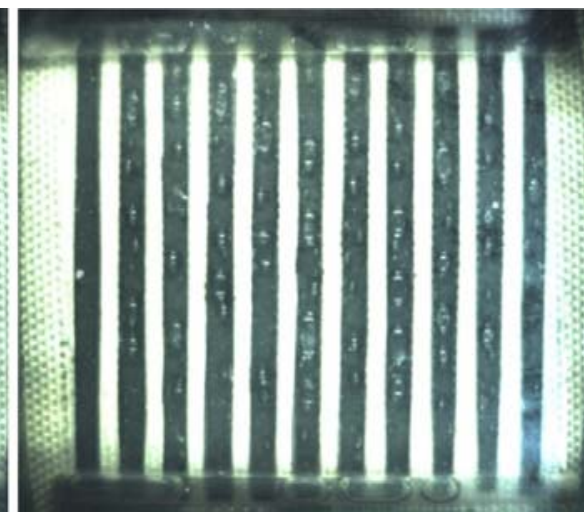

(c)

Fig. 3 Evolution of two-phase flow in DMFC anode flow bed in microgravity. a 1,000 ms. b 2,000 ms. c 3,000 ms 
by anode electrochemical reaction. The size of bubbles was bigger than that in normal gravity. Finally, the bubbles were detached from GDL and went into channels. The average rise velocity of bubbles in channels was $4.05 \mathrm{~mm} / \mathrm{s}$. The speed of bubbles rising in reduced gravity was obviously slower than that in normal gravity because buoyancy lift is very weak and the bubbles removal is governed by viscous drag of fluid in microgravity. Some bubbles coalesced with each other and formed a larger bubble. As shown in Fig. 3a and b, the longer the time, the bigger the bubbles. Slug flow appeared in certain of anode channels about $3 \mathrm{~s}$ after releasing capsule (Fig. 3c).

Although the electric resistor in external circuit was kept constant during the test, the performance of the fuel cell was influenced quite evidently as change of gravity. The output power density of fuel cells at $40 \mathrm{~ms}$ before microgravity is higher than that at 3,560 ms after releasing capsule (Fig. 4). The flow pattern in normal gravity was bubbly flow. The supply of anode reactant (methanol solution) was unhindered (Fig. 2). After microgravity lasting $3.56 \mathrm{~s}$, gas slugs had occupied most anode channels (Fig. 5). Being differ from typical slug flow, one of four sidewalls of channel was a penetrable porous meadia of GDL. The gas slugs blocked mass transfer of methanol solution from channels to anode catalyst layer through the GDL porous meadia and led to decline of cell performance.

Farther experimental results indicated that the gravity influences two-phase flow and mass transfer inside fuel cells. If the weakened mass transfer is serious enough, it would cause the concentration polarization, which reduces output performance of fuel cells. However, when the current density is pretty low, the fuel cells performance is dominated by not concentration

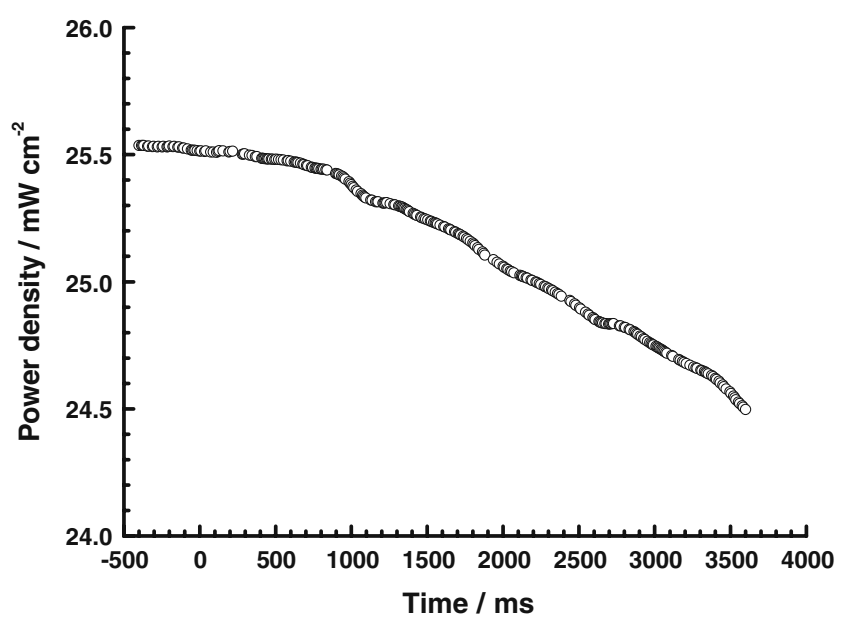

Fig. 4 Effect of gravity on output power density of fuel cells

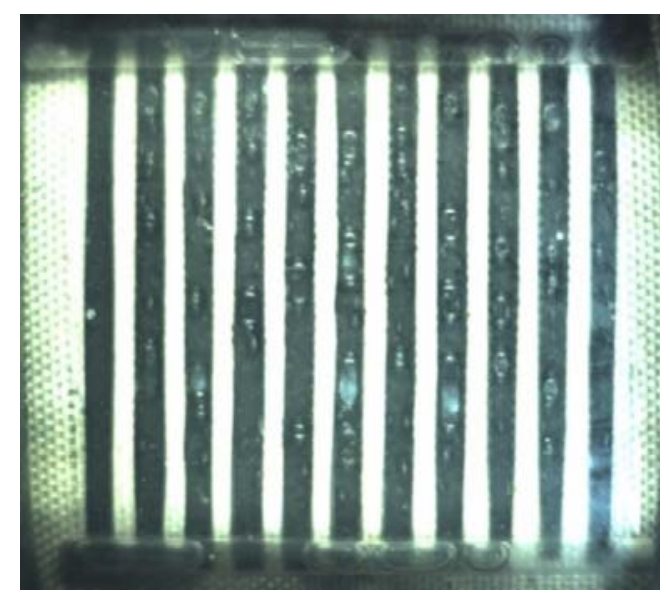

Fig. 5 Two-phase flow in anodechannels in reduced gravity (3,560 ms after releasing capsule)

polarization, but activation polarization. The effect of gravity is negligible in this situation. Along with the increase of current density, carbon dioxide accumulates continuously in channels and the size of bubbles is on the increase. The impact of gravity gradually become important. In the region of high current density, if the gas slugs or even gas columns occur in channels in microgravity, the performance of liquid fed direct methanol proton exchange membrane fuel cells will be failing rapidly.

The results infer that in long-term microgravity condition, flow field and operating condition must be optimized to ensure timely discharge of bubbles and avoid concentration polarization of fuel cells.

\section{Conclusions}

An in situ visual observation of two-phase flow inside direct methanol proton exchange membrane fuel cells in microgravity has been conducted.

(1) The gravity affects two-phase flow in fuel cells. In microgravity condition, the size of bubbles is bigger than that in normal gravity. The longer the time, the bigger the bubbles. The velocity of bubbles rising in channels is much slower than that in normal gravity because buoyant lift force is very weak in microgravity.

(2) The flow pattern in anode channels of liquid fed DMFCs could change from bubbly flow in normal gravity to slug flow in microgravity. The gas slugs blocked supply of reactants from channels to 
anode catalyst layer and led to degradation of cell performance in microgravity.

(3) The gravity influences mass transfer inside fuel cells. If the weakened mass transfer causes concentration polarization, the output performance of fuel cells will be reduced. However, if the current density is very low, the effect of gravity on the fuel cells performance is negligible.

Acknowledgements The authors are grateful to the National Natural Science Foundation of China for the financial support (Grant No.: 50406010) and to Senior Engineers Shi Xin WAN and Ming Gang WEI for their kindly help.

\section{References}

Argyropoulos, P., Scott, K., et al.: Gas evolution and power performance in direct methanol fuel cells. J. Appl. Electrochem. 29(6), 661-669 (1999a)

Argyropoulos, P., Scott, K., et al.: Carbon dioxide evolution in direct methanol fuel cells. Electrochim. Acta. 44(20), 35753584 (1999b)

Barbir, F., Molter, T., Dalton, L.: Efficiency and weight tradeoff analysis of regenerative fuel cells as energy storage for aerospace applications. Int. J. Hydrogen Energy 30(4), 351357 (2005)

Guo, H., Ma, C.F., et al.: Heat and mass transfer and two phase flow in hydrogen proton exchange membrane fuel cells and direct methanol fuel cells. In: Proceedings of First International Conference on Fuel Cell Science, Engineering and Technology, pp. 471-476. Rochester, NY, USA, 21-23 April (2003)

Guo, H., Jia, J.L., Kong, J., et al.: Two-phase flow in anode interdigital flow bed of a liquid fed direct methanol fuel cell. In: Proceedings of 13th International Heat Transfer Conference, paper number: ENR-04. Begell House, Sydney, Australia, 13-18 August 2006, (2006)

Guo, H., Zhao, J.F., Lv, C.P., et al.: Experimental study of fuel cells performance in short term microgravity condition. J. Eng. Thermophys. 29(5), 865-867 (2008)

Hakenjos, A., Muenter, H., Wittstadt, U., et al.: A PEM fuel cell for combined measurement of current and temperature distribution, and flow field flooding. J. Power Sources 131(1-2), 213-216 (2004)
Liu, X., Guo, H., Ma, C.F.: Water flooding and two-phase flow in cathode channels of proton exchange membrane fuel cells. J. Power Sources 156(2), 267-280 (2006)

Liu, X., Guo, H., Ye, F., et al.: Water flooding and pressure drop characteristics in flow channels of proton exchange membrane fuel cells. Electrochim. Acta. 52(11), 3607-3614 (2007)

Lu, G.Q., Wang, C.Y.: Electrochemical and flow characterization of a direct methanol fuel cell. J. Power Sources 134(1), 33-40 (2004)

Mench, M.M., Dong, Q.L., Wang, C.Y.: In situ water distribution measurements in a polymer electrolyte fuel cell. J. Power Sources 124(1), 90-98 (2003)

Nordlund, J., Picard, C., et al.: The design and usage of a visual direct methanol fuel cell. J. Appl. Electrochem. 34(8), 763770 (2004)

Scott, K., Argyropoulos, P., et al.: Electrochemical and gas evolution characteristics of direct methanol fuel cells with stainless steel mesh flow beds. J. Appl. Electrochem. 31(8), 823-832 (2001)

Scott, K., Taama, W.M., et al.: Engineering aspects of the direct methanol fuel cell system. J. Power Sources 79(1), 43-59 (1999)

Sone, Y., Ueno, M., Kuwajima, S.: Fuel cell development for space applications: fuel cell system in a closed environment. J. Power Sources 137(2), 269-276 (2004)

Sone, Y., Ueno, M., Naito, H., et al.: One kilowatt-class fuel cell system for the aerospace applications in a microgravitational and closed environment. J. Power Sources 157(2), 886-892 (2006)

Tüber, K., Pócza, D., Hebling, C.: Visualization of water buildup in the cathode of a transparent PEM fuel cell. J. Power Sources 124(2), 403-414 (2003)

Yang, H., Zhao, T.S., et al.: In situ visualization study of $\mathrm{CO}_{2}$ gas bubble behavior in DMFC anode flow fields. J. Power Sources 139(1-2), 79-90 (2005a)

Yang, H., Zhao, T.S., et al.: Pressure drop behavior in the anode flow field of liquid feed direct methanol fuel cells. J. Power Sources 142(1-2), 117-124 (2005b)

Yang, W.M., Chou, S.K., Shu, C.: Effect of current-collector structure on performance of passive micro direct methanol fuel cell. J. Power Sources 164(2), 549-554 (2007)

Yang, X.G., Zhang, F.Y., Lubawy, A.L., et al.: Visualization of liquid water transport in a PEFC. Electrochem, Solid-State Lett. 7(11), A408-A411 (2004)

Zhang, F.Y., Yang, X.G., Wang, C.Y.: Liquid water removal from a polymer electrolyte fuel cell. J. Electrochem. Soc. 153(2), A225-A232 (2006)

Zhang, J., Yin, G.P., Lai, Q.Z., et al.: The influence of anode gas diffusion layer on the performance of low-temperature DMFC. J. Power Sources 168(2), 453-458 (2007) 